Int. J. Electrochem. Sci., 11 (2016) $5891-5899$

International Journal of

ELECTROCHEMICAL

SCIENCE

www.electrochemsci.org

\title{
Voltammetric Investigation for Electron-Transfer Characteristics of Organic Semiconductors
}

\author{
Ji-Eun Park, Sunga Song and Ik-Soo Shin ${ }^{*}$ \\ Department of Chemistry, Soongsil University, Dongjak-gu, Seoul 156-743, Republic of Korea \\ *E-mail: extant@ssu.ac.kr
}

doi: $10.20964 / 2016.07 .14$

Received: 22 March 2016 / Accepted: 29 April 2016 / Published: 4 June 2016

Two voltammertic techniques, cyclic voltammetry (CV) and chronocoulometry (CC), were employed to investigate the redox characteristics of two organic semiconductors in organic light-emitting diodes (OLED), fac-tris(2-phenylpyridine)iridium $\left(\operatorname{Ir}(\mathrm{ppy})_{3}\right)$ and $\mathrm{N}, \mathrm{N}^{\prime}-\operatorname{di}\left(1-\right.$ naphthyl)-N,N $\mathrm{N}^{\prime}$-diphenyl-(1,1 ' biphenyl)-4,4'-diamine (NPB). The electron-transfer characteristics including of oxidation formal potentials $\left(E^{\mathrm{o}}\right)$, diffusion coefficients $\left(D_{\mathrm{o}}\right)$, electron-transfer rate constants $\left(k^{\mathrm{o}}\right)$ were estimated by the combination of $\mathrm{CV}$ and $\mathrm{CC}$ measurements. The energy level of the highest-occupied molecular-orbital $\left(E_{\mathrm{HOMO}}\right)$ was also found by quantitative relationship between the oxidation potential and the ionization energy.

Keywords: $f a c$-tris(2-phenylpyridine)iridium, N,N'-di(1-naphthyl)-N,N'-diphenyl-(1,1'-biphenyl)-4,4'diamine, highest-occupied molecular-orbital, cyclic voltammetry, chronocoulometry, Anson plot, Nicholson method, quasi-reversible process, electron-transfer rate constant, diffusion coefficient, oxidation formal potentials

\section{FULL TEXT}

(C) 2016 The Authors. Published by ESG (www.electrochemsci.org). This article is an open access article distributed under the terms and conditions of the Creative Commons Attribution license (http://creativecommons.org/licenses/by/4.0/). 